\title{
SODIUM MONOFLUOROACETATE (1080) BAIT-SHYNESS IN A WILD BRUSHTAIL POSSUM (TRICHOSURUS VULPECULA) POPULATION
}

\author{
S.C. OGILVIE, M.D. THOMAS, H. FITZGERALD \\ and D.R. MORGAN \\ Manaaki Whenua - Landcare Research, P.O. Box 69, Lincoln
}

\begin{abstract}
Bait-shyness was investigated in wild possums by comparing the consumption of diced carrot with consumption of non-toxic cereal bait before and after the population had been poisoned with the same cereal bait containing $0.04 \%$ sodium monofluoroacetate (1080). Before poisoning, $64 \%$ of the total bait consumed was cereal, whereas after poisoning cereal bait consumption declined to $3-4 \%$. To determine whether any individual component of the cereal bait cues possum avoidance, the consumption of plain cereal bait, cereal bait with green dye, and cereal bait with cinnamon lure were also measured. Possums remained shy of the cereal bait even when the dye and lure were absent. Ways to overcome bait-shyness are discussed in light of these new findings.

Keywords: bait-shyness, sodium monofluoroacetate, brushtail possum, Trichosurus vulpecula, vertebrate pest control
\end{abstract}

\section{INTRODUCTION}

Aerial and ground application of bait containing sodium monofluoroacetate (1080) are cost-effective means of reducing possum numbers in large areas where this species is threatening conservation and/or agricultural values (Livingstone 1994). However, there is growing evidence that possums consuming sub-lethal amounts of 1080 bait learn to recognise the bait as harmful, and subsequently become reluctant to eat them again, i.e., they develop a prolonged learned aversion to the bait and become "bait-shy" (Hickling 1994; Morgan 1996). Aversion to 1080 bait has also been reported in rodent populations; deer mice (Peromyscus maniculatus) have shown reluctance to consume 1080 bait, 8 months after sublethal ingestion (Howard et al. 1977). An important implication of these observations is that successive control operations using 1080 are likely to diminish in effectiveness. It is therefore important to try and avoid shyness (Henderson and Morriss 1996) by using high quality, palatable and effective baits to achieve $>90 \%$ kill rate. However, in cases where bait shyness is suspected, alternative control methods may be required.

At present, managers are unable to determine whether possum populations are bait-shy. Bait-shyness could be determined by comparing the consumption of a bait similar to that previously used for poisoning with the consumption of a contrasting bait type. Bait-shy possums will presumably show an aversion to bait they associate with the trauma of sub-lethal poisoning, so the relative proportions of the two bait types consumed will be different from that seen with a naïve population.

The aims of this study were to induce 1080 bait-shyness in a wild possum population, to investigate the bait preferences of this population before and after induction of bait-shyness, and to determine whether bait-shyness is a response to any individual bait component. 


\section{MATERIALS AND METHODS}

The investigation was conducted in a 12 ha area of mixed forest consisting predominantly of pines and oaks, at Kirwee, $35 \mathrm{~km}$ west of Christchurch, New Zealand. Sodium monofluoroacetate (95\% purity) was obtained from Sigma Chemical Company, St Louis, USA, and "No. 7" compressed cereal pellets were obtained from Animal Control Products, Wanganui, New Zealand.

In order to measure possum bait preferences before poisoning, 20 "Kilmore" bait stations were placed on a grid pattern at approximately $100 \mathrm{~m}$ intervals. Ten randomly selected bait stations contained $1 \mathrm{~kg}$ each of green-dyed, cinnamon-lured, non-toxic No. 7 cereal bait, while the other 10 stations contained $1 \mathrm{~kg}$ each of carrot, cut into pieces of approximately $3 \mathrm{~g}$. The amount of bait consumed at each bait station was measured daily for 4 consecutive days, and mean consumption was calculated for each treatment.

After 4 days, green-dyed, cinnamon-lured, No. 7 cereal bait containing $0.04 \%$ 1080 (certified by Landcare Research Toxicology Laboratory) was evenly distributed by hand on the ground throughout the study area at a rate of $5 \mathrm{~kg} / \mathrm{ha}$, in order to simulate aerial application of bait. At this concentration of 1080 an average sized possum $(3 \mathrm{~kg})$ would have to eat $>4$ baits to receive a lethal dose, based on an $L_{50}$ of $1.0 \mathrm{mg} / \mathrm{kg}$ (McIlroy 1982). In normal control operations the concentration of 1080 in baits is high enough to ensure that most possums are killed after eating one or two baits. The lower concentration was chosen to deliberately increase the likelihood of individuals receiving a sub-lethal dose, and therefore becoming bait-shy.

To determine the percentage of possums killed, $1008 \mathrm{~g}$ wax blocks containing $0.1 \%$ orange flavour (Bush, Boake and Allen, Auckland) were set on wooden spatulas placed individually in the ground at approximately $20 \mathrm{~m}$ intervals around the circumference of the study site before and after poisoning. After 1 night they were collected and the number that were bitten by possums was recorded as an index of population density. An estimate of the percentage of possums killed by the toxic bait was calculated from the number of flavoured wax blocks bitten by possums (Thomas and Meenken 1995) before and after poisoning.

Consumption of non-toxic bait was measured again (as described above) 2 weeks and 11 weeks after the toxic bait was distributed. Differences in mean consumption were compared using t-tests to establish whether there was a change in the preference for cereal bait relative to carrot bait before and after poisoning.

In order to determine whether any individual component of the bait acts as a cue to elicit a bait-shyness response, 30 "Kilmore" bait stations were placed at evenlyspaced sites throughout the study area. Each of 10 randomly selected stations were filled with $1 \mathrm{~kg}$ of either plain non-toxic cereal bait, cinnamon-lured non-toxic cereal bait, or green-dyed non-toxic cereal bait. The amount of each bait type consumed was measured daily for 4 consecutive days. Analysis of variance was used to compare the consumption of each treatment with the consumption of carrot in the first post-poison preference trial, undertaken 2 weeks earlier.

\section{RESULTS AND DISCUSSION}

Before the poison was presented, $47 \%$ of the wax blocks distributed throughout the study area were bitten by possums, compared to only $17 \%$ after exposure to toxic bait. Assuming the poisoning operation did not induce avoidance of any new potential food materials, these results indicate that approximately $64 \%$ of the possum population in the study area was killed by the low-dose 1080 bait.

Before poisoning, the study population preferred cereal bait to carrot bait (Fig. 1A), with cereal making up $64 \%$ of the total bait eaten. Two weeks after poisoning, only $3 \%$ of the total bait consumed was cereal. This apparent aversion persisted for the duration of the study, with cereal consumption comprising only $4 \%$ of the total bait eaten 11 weeks after exposure (Fig. 1B). The mean proportions of cereal bait eaten at both 2 and 11 weeks after exposure to toxic bait were significantly different $(\mathrm{P}<0.001$ in both cases) from that seen prior to poisoning. The possums that survived the poisoning operation were likely to have consumed a sub-lethal amount of bait, and 


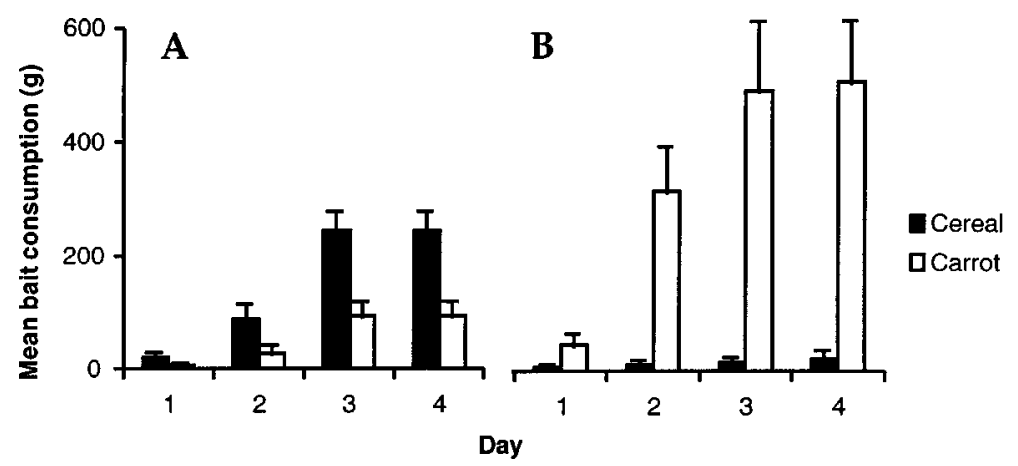

FIGURE 1: Mean daily consumption of non-toxic cereal bait and carrot, A) prior to exposure to toxic 1080 cereal bait, B) 11 weeks after poisoning with 1080 cereal bait. Error bars represent 1 standard error.

therefore became reluctant to eat the cereal bait. However, it is possible that only a proportion of the population ate cereal bait and this proportion was killed, leaving only carrot-eating possums. While this possibility cannot be ruled out, we consider it is unlikely, because the $0.04 \% 1080$ concentration in the baits was not expected to kill all possums eating the baits, and because previous studies have shown that $95 \%$ or more of possums encountering non-toxic (Morgan 1982) and toxic cereal bait (Morgan 1990) eat at least one full-sized pellet.

The methods used in this study could also be used to indicate bait-shyness in other possum populations. Two steps would need to be taken in order to do this. Firstly, the bait preferences of populations that have not been poisoned would have to be established. In the present study, possums consumed about twice as much cereal as carrot before poisoning. Secondly, in any particular area where a bait-shy population is suspected, it will be essential to check records of the baits and toxic agents that have been used. If, for example, cereal 1080 bait has been used, then an indication of baitshyness could be gained by comparing consumption of non-toxic cereal bait of the same type previously used with a bait type that is new to the population.

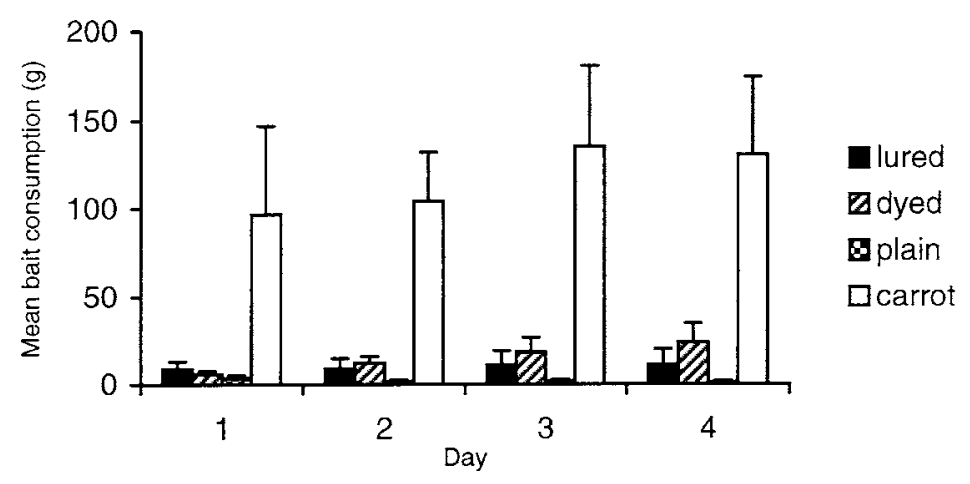

FIGURE 2: Mean daily consumption of cinnamon lured, green dyed, and plain non-toxic cereal bait, compared to carrot intake following exposure to 1080 cereal bait. Error bars represent 1 standard error. 
Plain cereal bait, cereal bait with cinnamon lure, and cereal bait dyed green were all consumed to a much lesser extent than carrot following exposure to toxic cereal baits (Fig. 2) ( $\mathrm{P}<0.002$ in all cases). No individual bait component was identified as the cue that elicited bait aversion in this study. This may indicate that repeated poisoning using the same base bait material is less likely to be successful than if a different base material is used. If repeated poisoning is planned, it appears prudent to use a bait type that possums have not been exposed to previously.

\section{ACKNOWLEDGEMENTS}

The authors would like to thank Hugh and Helen Williams and the Selwyn Plantation Board for allowing us access to the study site, Grant Morriss for technical assistance, Charles Eason, Megan Ogle-Mannering, Mark Wickstrom and Richard Barker for statistical advice. The study was funded by the Animal Health Board and the Foundation for Research, Science and Technology (Technologies for sustained vertebrate pest control programme).

\section{REFERENCES}

Henderson, R.J. and Morriss, G., 1996. Sub-lethal poisoning of possum with acute pesticides used in bait stations. Proc. 49th N.Z. Plant Prot. Conf.: (this volume).

Hickling, G.J., 1994. Behavioural resistance by vertebrate pests to 1080 toxin: implications for sustainable pest management in New Zealand.In: A.A. Seawright and C.T. Eason (Eds); Proceedings of the science workshop on 1080. The Roy. Soc. N.Z., Misc. Ser. 28:151-158.

Howard, W.E., Marsh, R.E., and Cole, R.E., 1977. Duration of associative memory to toxic bait in deer mice. J. Wildl. Manage. 41:484.

Livingstone, P.G., 1994. The use of 1080 in New Zealand.In: A.A. Seawright and C.T. Eason (Eds); Proceedings of the science workshop on 1080. The Roy. Soc. N. Z., Misc. Ser. 28:1-9.

McIlroy, J.C., 1982. The sensitivity of Australian animals to 1080 poison. III. Marsupial and eutherian herbivores. Aust. Wildl. Res. 9:487-503.

Morgan, D.R., 1982. Field acceptance of non-toxic and toxic baits by populations of the brushtail possum (Trichosurus vulpecula Kerr). N.Z. J. Ecol. 5:36-43.

Morgan, D.R., 1990. Behavioural response of brushtail possums Trichosurus vulpecula to baits used in pest control. Aust. Wildl. Res. 17:601-613.

Morgan, D.R., 1996. Induced 1080 bait-shyness in captive brushtail possums and implications for management. Wildl. Res. 23:207-211.

Thomas, M.D. and Meenken, D., 1995. Comparison of ground-laid 1080 paste baits and 1080 cereal baits in bait stations for possum control on farmland. Landcare Research Contract Report LC9596/35 (unpubl.) 12 p. 